Check for updates

Cite this: Chem. Sci., 2019, 10, 8179

๑ All publication charges for this article have been paid for by the Royal Society of Chemistry

\section{Monitoring NAD(P)H by an ultrasensitive fluorescent probe to reveal reductive stress induced by natural antioxidants in HepG2 cells under hypoxia $\uparrow$}

\author{
Xiaohong Pan, (D) ab Yuehui Zhao, ${ }^{a}$ Tingting Cheng, ${ }^{\mathrm{b}}$ Aishan Zheng, ${ }^{\mathrm{a}}$ Anbin Ge, \\ Lixin Zang, ${ }^{a}$ Kehua Xu (D) *a and Bo Tang (D) *a
}

Reductive stress, the opposite of oxidative stress, represents a disorder in the redox balance state which is harmful to biological systems. For decades, the role of oxidative stress in tumor therapy has been the focus of attention, while the effects of reductive stress have been rarely studied. Here, we report the anti-cancer effects of reductive stress induced by three natural antioxidants (resveratrol, curcumin and celastrol). Considering the fact that the solid tumor microenvironment suffers from hypoxia, we performed cell experiments under hypoxic conditions. In order to observe the reductive stress, we first developed an ultrasensitive fluorescent probe (TCF-MQ) for specifically imaging $N A D(P) H$ which is a marker of reductive stress. TCF-MQ responded to $\mathrm{NAD}(\mathrm{P}) \mathrm{H}$ rapidly and exhibited high sensitivity with a detection limit of $6 \mathrm{nM}$. With the help of TCF-MQ, we found that upon the treatment of HepG2 cells with pharmacological doses of three natural antioxidants under hypoxic conditions, high levels of $N A D(P) H$ were produced before cell death. The excess $\mathrm{NAD}(\mathrm{P}) \mathrm{H}$ resulted in reductive stress instead of oxidative stress. In contrast, under normoxic conditions, there was no reductive stress involved in the process of cell death induced by three natural antioxidants. Therefore, we hypothesize that the mechanism of cancer cell death induced by natural antioxidants under hypoxia should be attributed to the reductive stress.
Received 24th April 2019 Accepted 14th July 2019

DOI: $10.1039 / c 9 s c 02020 a$

rsc.li/chemical-science a common feature in the above studies, that is, the tumor cells used in the experiments are all cultured under normoxic conditions $\left(20 \% \mathrm{O}_{2}\right)$, there is abundant oxygen around the cells, which provides conditions for the production of reactive oxygen species. ${ }^{7}$ But this condition is obviously contrary to the hypoxic microenvironment of solid tumors. ${ }^{8,9}$ Hypoxia is a common feature in solid tumors. In hepatocellular carcinoma (HCC), the $\mathrm{O}_{2}$ values in most areas is in the range of $0-10 \mathrm{~mm} \mathrm{Hg}(0-$ $1.32 \%){ }^{10}$ Therefore, in this study, we revealed a new anti-cancer mechanism of three natural antioxidants (resveratrol, curcumin and celastrol) under simulated tumor hypoxic conditions.

The redox balance in the body is fundamental to sustain life. Once redox imbalanced, cell damage and apoptosis are inevitable. ${ }^{11-13}$ For decades, studies of the anti-tumor effects of natural antioxidants have been focused on oxidative stress. However, reductive stress, another way of redox imbalance, is rarely noticed. Similar to oxidative stress, reductive stress also represents a disturbance in the redox state which can cause body damage and lead to cell death. ${ }^{14-16}$ Recently, reductive stress was defined as an excessive amount of reducing equivalents, and excess $\mathrm{NAD}(\mathrm{P}) \mathrm{H}$ and/or GSH is considered a marker of reductive stress. ${ }^{14,17,18}$

$\mathrm{NAD}(\mathrm{P}) \mathrm{H}$, the general term of the nicotinamide adenine dinucleotide (NAD) derivatives $\mathrm{NADH}$ and $\mathrm{NADPH},{ }^{19}$ is

$\dagger$ Electronic supplementary information (ESI) available. See DOI: $10.1039 / \mathrm{c} 9 \operatorname{sc} 02020 \mathrm{a}$ 

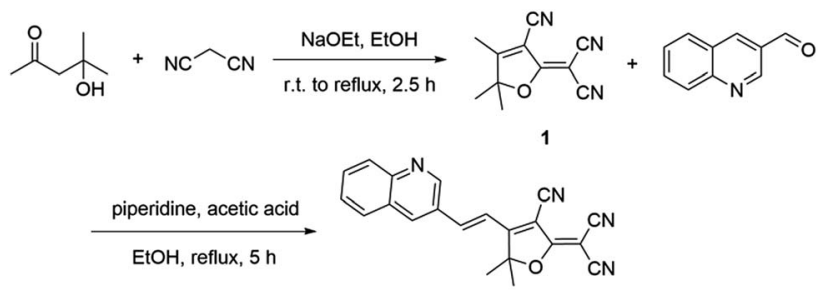

2

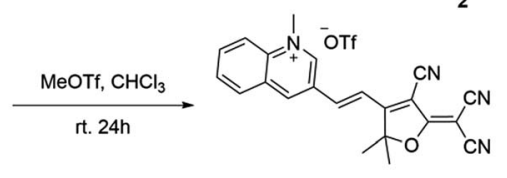

TCF-MQ

Scheme 1 Synthesis of TCF-MQ.

a universal electron carrier in cellular processes. NAD(P)H and $\operatorname{NAD}(\mathrm{P})^{+}$undergo reversible oxidation-reduction in many biological reactions, ${ }^{20}$ and the level of $\mathrm{NAD}(\mathrm{P}) \mathrm{H}$ is tightly linked to the redox environment in cells. Insufficient $\mathrm{NAD}(\mathrm{P}) \mathrm{H}$ induces oxidative stress due to increased ROS production, while excessive $\mathrm{NAD}(\mathrm{P}) \mathrm{H}$ leads to reductive stress because it cannot be properly oxidized. ${ }^{20}$ Besides, $\mathrm{NAD}(\mathrm{P}) \mathrm{H}$ is a highly reducible dynamic molecule with very high reactivity and instability which cannot be easily detected in cell and animal models. Therefore, an ultrasensitive and rapid method to selectively determine $\mathrm{NAD}(\mathrm{P}) \mathrm{H}$ in vivo must be developed to investigate the reductive stress.

Fluorescent probes are a powerful tool for direct visualization of biomolecules in vivo with high sensitivity and short response times. $^{21,22}$ To date, several detection methods for reductive stress have been reported, ${ }^{23-25}$ and in particular, several small-molecule fluorescent probes for detecting $\mathrm{NAD}(\mathrm{P})$ $\mathrm{H}$ have been developed. ${ }^{26-31}$ Louie $e t$ al. synthesized a NADHsensitive multimodal magnetic-resonance/optical-imaging contrast agent and successfully applied it in cells. ${ }^{27}$ Komatsu reported a ubiquinone-rhodol-derived fluorescent probe for imaging intracellular NAD(P)H. ${ }^{29}$ Recently, Chang et al. developed a boronic acid-containing fluorescent probe for NADH based on resazurin, which shows dramatically improved sensitivity (detection limit: $0.084 \mu \mathrm{M}$ ) by introducing boronic acid to bind with NADH. ${ }^{31}$ In addition, our group previously developed a near-infrared small-molecule fluorescent probe (DCI-MQ) based on dicyanoisophorone for monitoring of $\mathrm{NAD}(\mathrm{P}) \mathrm{H}$ in cells. ${ }^{32}$ This probe was successfully used to selectively detect endogenous $\mathrm{NAD}(\mathrm{P}) \mathrm{H}$ in cells with a detection limit of $12 \mathrm{nM}$. Although the above methods for detecting $\mathrm{NAD}(\mathrm{P}) \mathrm{H}$ are suitable for cell use, these methods are not suitable for monitoring the reductive stress due to their lower sensitivity.

Here, we designed and synthesized an ultrasensitive smallmolecule fluorescent probe (TCF-MQ) for better detecting NAD(P)H. TCF-MQ uses a more electron-absorbing tricyanofuran as the chromophore which endows the probe with good sensitivity for $\mathrm{NAD}(\mathrm{P}) \mathrm{H}$ with a limit of detection (LOD) of $6 \mathrm{nM}$. This probe was successfully used to distinguish different levels of $\mathrm{NAD}(\mathrm{P}) \mathrm{H}$ in HepG2 cells under normoxic and hypoxic

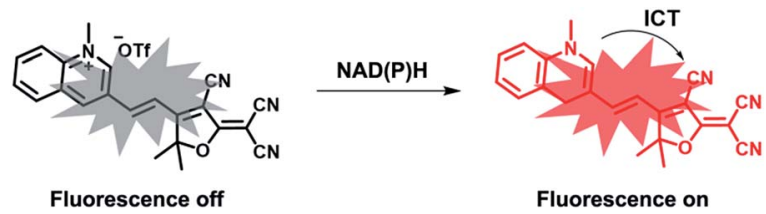

Scheme 2 TCF-MQ for fluorescence detection of NAD(P)H.

conditions. Furthermore, with the help of TCF-MQ, we found that high levels of $\mathrm{NAD}(\mathrm{P}) \mathrm{H}$ were produced before cell death after the treatment of HepG2 cells with pharmacological doses of natural antioxidants (resveratrol, curcumin and celastrol) under hypoxic conditions. The excess $\mathrm{NAD}(\mathrm{P}) \mathrm{H}$ resulted in reductive stress which might induce cell death.

\section{Results and discussion}

\section{Design and synthesis of TCF-MQ}

2-Dicyanomethylene-3-cyano-4,5,5-trimethyl-2,5-dihydrofuran (TCF) as a strong electron-withdrawing group has been widely used in non-linear optical materials. ${ }^{33,34}$ TCF-based fluorophores typically have a donor- $\pi$-acceptor $(D-\pi-A)$ structure with long emission wavelengths, and many fluorescent probes have been developed. ${ }^{35}$ Here, we designed and synthesized a TCF-based fluorescent probe (TCF-MQ) for the detection of $\mathrm{NAD}(\mathrm{P}) \mathrm{H}$ (Scheme 1). TCF-MQ and all intermediate structures were fully characterized by ${ }^{1} \mathrm{H}$ NMR, ${ }^{13} \mathrm{C}$ NMR, and HRMS (see the Experimental section and the ESI $\dagger$ ).

The proposed recognition mechanism of TCF-MQ toward $\mathrm{NAD}(\mathrm{P}) \mathrm{H}$ is shown in Scheme 2. The active hydrogen atom of
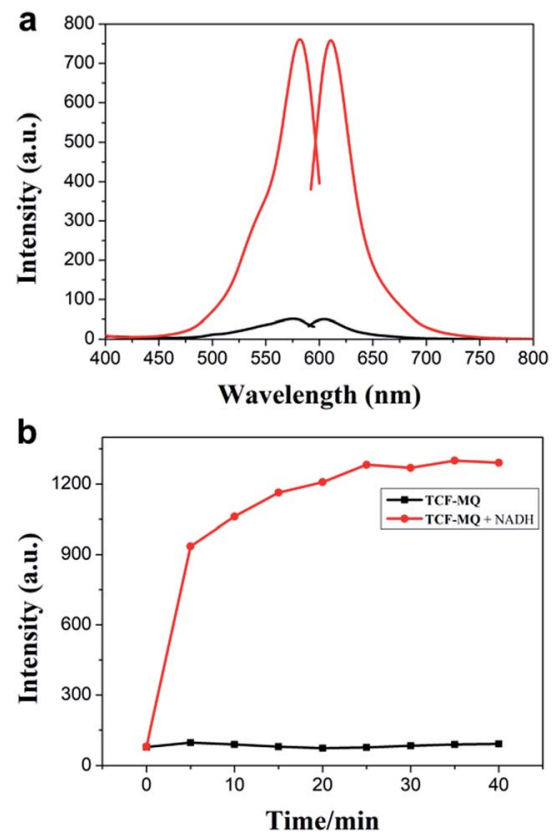

Fig. 1 (a) Excitation and emission spectra of TCF-MQ (black) and the product of TCF-MQ with NADH (red). (b) Time-dependent fluorescence changes of TCF-MQ $(10 \mu \mathrm{M})$ upon the addition of NADH (50 $\mu \mathrm{M})$. 
$\mathrm{NAD}(\mathrm{P}) \mathrm{H}$ was added to the quinolinium moiety of the probe to form an adduct. To verify the sensing mechanism of TCF-MQ for NADH, the probe TCF-MQ and the product of TCF-MQ with NADH were analyzed by ESI-HRMS and ${ }^{1} \mathrm{H}$ NMR spectroscopy. Once the reaction of TCF-MQ with NADH was completed, a mass peak at $353.1477(\mathrm{~m} / \mathrm{z}$ calcd $=353.1396)$ belonging to the reaction product was observed (Scheme 2 and Fig. S1 $\dagger$ ). From the ${ }^{1} \mathrm{H}$ NMR analysis, after the reaction of TCFMQ with $\mathrm{NADH}$, the $\mathrm{N}-\mathrm{CH}_{3}$ protons of TCF-MQ shifted upfield from 4.68 to $3.54 \mathrm{ppm}$, and a new singlet at $3.87 \mathrm{ppm}$ emerged (Fig. S2 $\dagger$ ). These data confirmed our proposed recognition mechanism.

\section{Fluorescence sensing performance analysis of TCF-MQ}

The spectral properties of the probe with or without NADH were studied in PBS buffer solution (0.5\% DMSO, $10 \mathrm{mM}$ PBS, $\mathrm{pH}=$ 7.4). As shown in Fig. 1a, the probe displayed a weaker fluorescence peak at $604 \mathrm{~nm}\left(\lambda_{\mathrm{ex}}=576 \mathrm{~nm}\right)$. As expected, after the reaction of the probe with $\mathrm{NADH}$, a significant fluorescence enhancement at $610 \mathrm{~nm}\left(\lambda_{\mathrm{ex}}=582 \mathrm{~nm}\right)$ was observed (quantum yield $=0.064)$. Meanwhile, the fluorescence intensity at $610 \mathrm{~nm}$ was enhanced gradually and reached a plateau within $25 \mathrm{~min}$ (Fig. 1b). The effect of $\mathrm{pH}$ on the fluorescence detection of NADH with TCF-MQ was also investigated, which indicated that TCF-MQ responded to NADH well under physiological conditions (at $37^{\circ} \mathrm{C}$ and $\mathrm{pH}=7.4$ ) (Fig. S3†).

Next, we investigated the sensitivity of the probe to NADH. The spectra of the solution of TCF-MQ treated with different concentrations of $\mathrm{NADH}(0$ to $50 \mu \mathrm{M})$ were recorded. Upon
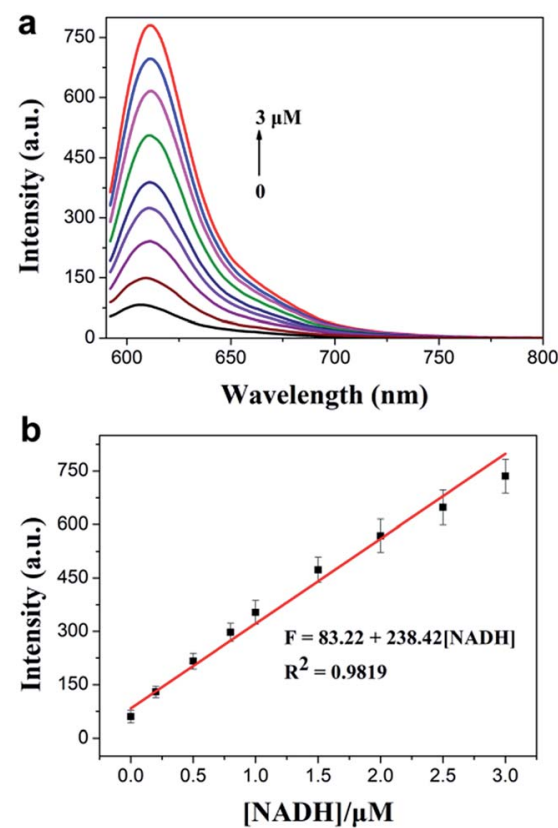

Fig. 2 (a) Fluorescence intensity changes of TCF-MQ $(10 \mu M)$ upon the addition of different concentrations of NADH $(0-3 \mu \mathrm{M})$ in PBS (10 mM, pH 7.4, 0.5\% DMSO as a cosolvent) at $37^{\circ} \mathrm{C}$ for $30 \mathrm{~min}$. (b) The linear correlation between emission intensities and concentrations of $\mathrm{NADH} . \lambda_{\mathrm{ex}}=582 \mathrm{~nm}, \lambda_{\mathrm{em}}=610 \mathrm{~nm}$, slit width: $5 \mathrm{~nm} / 5 \mathrm{~nm}$.

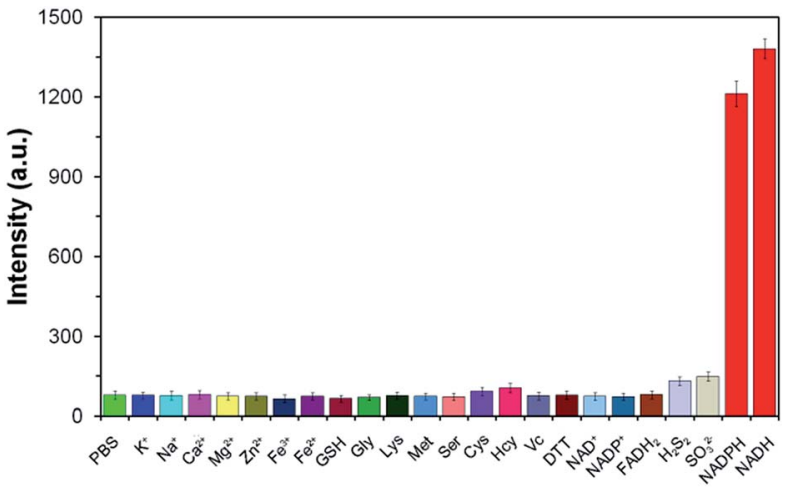

Fig. 3 Fluorescence responses of the probe TCF-MQ $(10 \mu \mathrm{M})$ for various analytes: $1 \mathrm{mM} \mathrm{K}^{+}, \mathrm{Na}^{+}, \mathrm{Ca}^{2+}, \mathrm{Mg}^{2+}, \mathrm{Zn}^{2+}, \mathrm{Fe}^{3+}, \mathrm{Fe}^{2+}, \mathrm{GSH}, \mathrm{Gly}$, Lys, Met, or Ser; $100 \mu \mathrm{M}$ Cys, Hcy, VC, or DTT; $5 \mu \mathrm{M} \mathrm{H}_{2} \mathrm{~S}_{2}$ or SO $_{3}{ }^{2-}$; and $50 \mu \mathrm{MNAD}^{+}, \mathrm{NADP}^{+}, \mathrm{FADH}_{2}, \mathrm{NADPH}$, or $\mathrm{NADH}$.

treatment with $\mathrm{NADH}$, the fluorescence intensities at $610 \mathrm{~nm}$ gradually increased with increasing concentrations of $\mathrm{NADH}$ (Fig. S4 $\dagger$ ), and there was a good linearity between the fluorescence intensities and $\mathrm{NADH}$ concentrations in the range of $0-3$

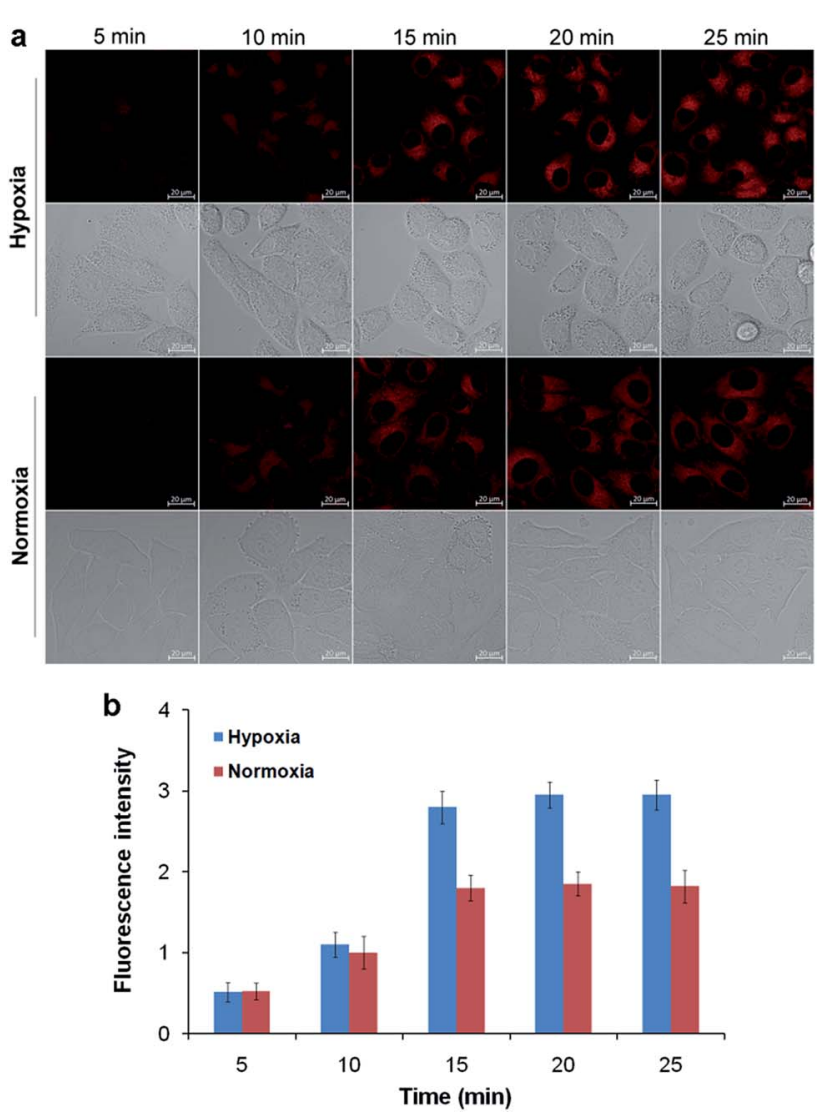

Fig. 4 Fluorescence imaging of $\mathrm{NAD}(\mathrm{P}) \mathrm{H}$ in living cells. HepG2 cells were cultured under hypoxic $\left(1 \% \mathrm{O}_{2}\right)$ or normoxic $\left(20 \% \mathrm{O}_{2}\right)$ conditions for $12 \mathrm{~h}$, and then incubated with $10 \mu \mathrm{M} \mathrm{TCF}-\mathrm{MQ}$ probe for 5-25 min. (a) The fluorescence images were obtained using confocal microscopy. (b) The fluorescence intensity was quantified based on the results of the relative fluorescence intensity per cell in the scanned area. The scale bar in all fluorescence images of cells is $20 \mu \mathrm{m}$. 


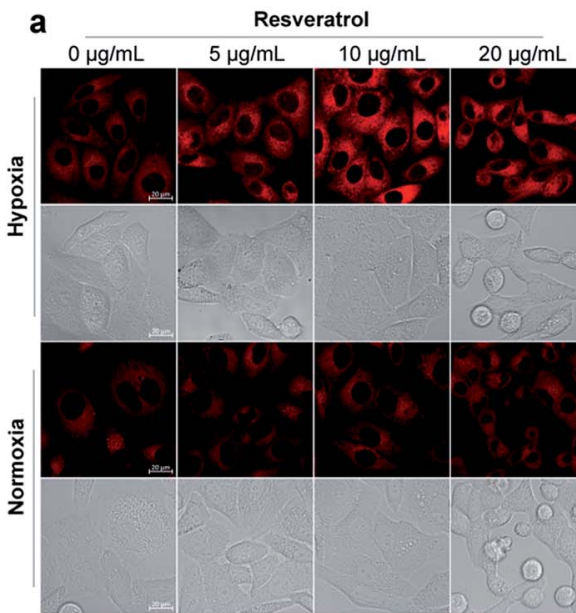

d

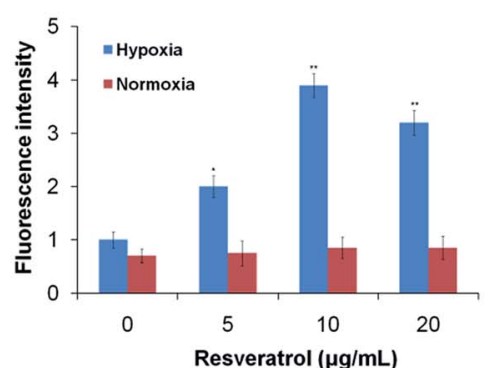

g

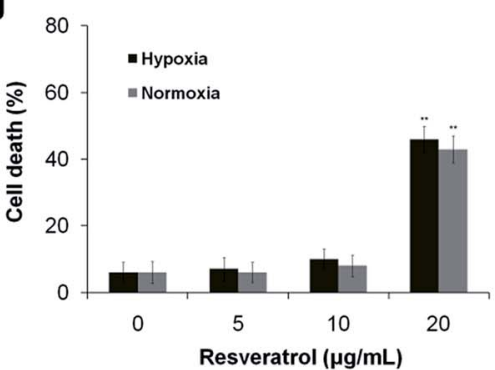

b b $\frac{\text { Curcumin }}{0 \mu \mathrm{g} / \mathrm{mL} \quad 5 \mu \mathrm{g} / \mathrm{mL} \quad 10 \mu \mathrm{g} / \mathrm{mL} \quad 20 \mu \mathrm{g} / \mathrm{mL}}$
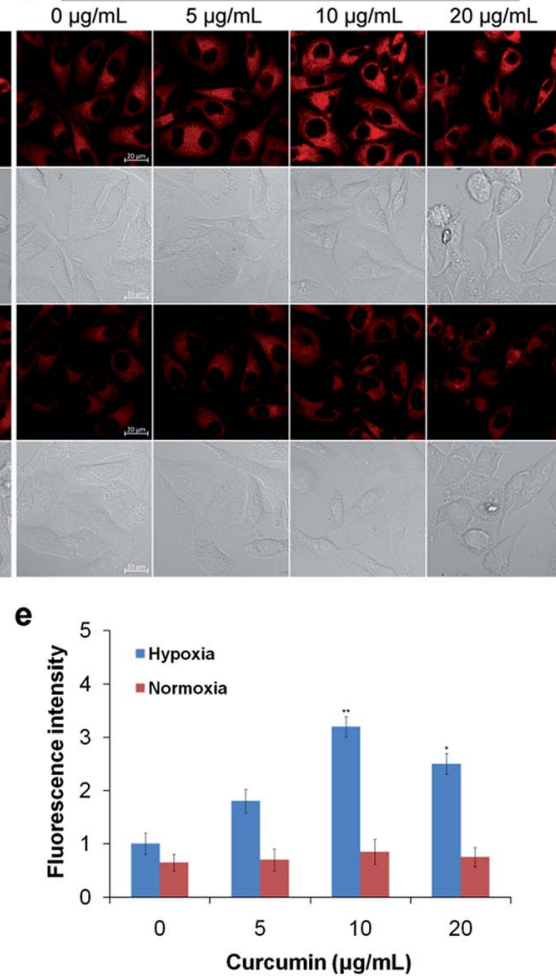

h

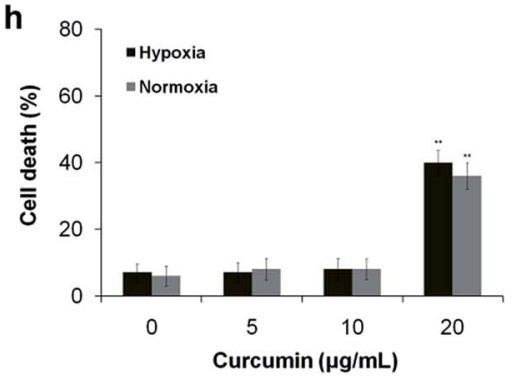

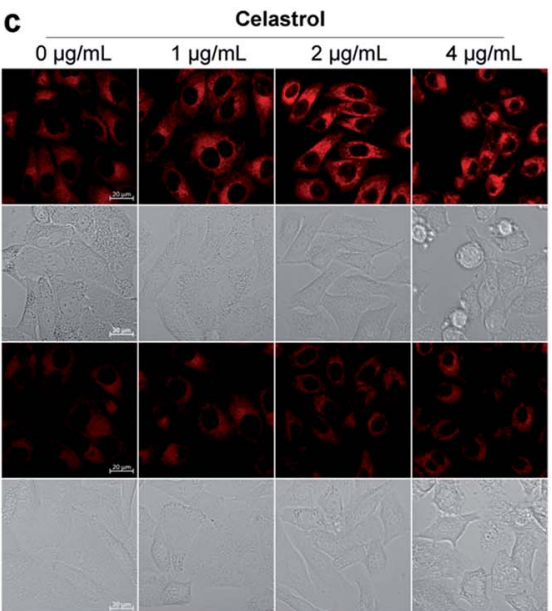

f
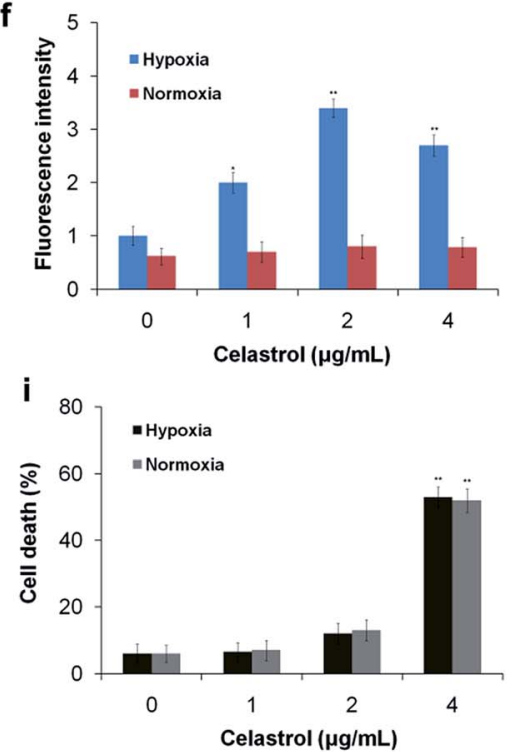

Fig. 5 Detection of NAD(P)H levels induced by natural antioxidants in living cells. (a) HepG2 cells were exposed to $0-20 \mu \mathrm{g} \mathrm{mL}{ }^{-1}$ resveratrol for $6 \mathrm{~h}$ under hypoxic conditions $\left(1 \% \mathrm{O}_{2}\right)$ and normoxic conditions $\left(20 \% \mathrm{O}_{2}\right)$, and then the cells were incubated with $10 \mu \mathrm{M} \mathrm{TCF}-\mathrm{MQ}$ probe for 20 min before the fluorescence images were obtained using confocal microscopy. (b) HepG2 cells were exposed to $0-20 \mu \mathrm{g} \mathrm{mL}{ }^{-1} \mathrm{curcumin}$ for $6 \mathrm{~h}$ under hypoxic conditions $\left(1 \% \mathrm{O}_{2}\right)$ and normoxic conditions $\left(20 \% \mathrm{O}_{2}\right)$, and then the cells were treated using the method described in (a). (c) HepG2 cells were exposed to $0-4 \mu \mathrm{g} \mathrm{mL}^{-1}$ celastrol for $6 \mathrm{~h}$ under hypoxic conditions $\left(1 \% \mathrm{O}_{2}\right)$ and normoxic conditions $\left(20 \% \mathrm{O}_{2}\right)$, and then the cells were treated using the method described in (a). ( $d-f)$ The fluorescence intensity in the experiments in $(a-c)$ was quantified based on the results of the relative fluorescence intensity per cell in the scanned area. (g) HepG2 cells were exposed to $0-20 \mu \mathrm{g} \mathrm{mL}{ }^{-1}$ resveratrol for $6 \mathrm{~h}$ under hypoxic conditions $\left(1 \% \mathrm{O}_{2}\right)$ and normoxic conditions $\left(20 \% \mathrm{O}_{2}\right)$, and then the cells were collected and stained with trypan blue. (h) HepG2 cells were exposed to $0-20 \mu \mathrm{g} \mathrm{mL}^{-1}$ curcumin for $6 \mathrm{~h}$ under hypoxic conditions $\left(1 \% \mathrm{O}_{2}\right)$ and normoxic conditions $\left(20 \% \mathrm{O}_{2}\right)$, and then the cells were collected and stained with trypan blue. (i) HepG2 cells were exposed to $0-4 \mu \mathrm{g} \mathrm{mL}^{-1}$ celastrol for $6 \mathrm{~h}$ under hypoxic conditions ( $1 \% \mathrm{O}_{2}$ ) and normoxic conditions $\left(20 \% \mathrm{O}_{2}\right)$, and then the cells were collected and stained with trypan blue $(* p<0.05, * * p 0.01, t$ test). The scale bar in all fluorescence images of cells is $20 \mu \mathrm{m}$.

$\mu \mathrm{M}$ (Fig. 2a). The regression equation is $F=83.22+238.42$ $[\mathrm{NADH}]$, with a linear coefficient of 0.9819 . The limit of detection (LOD) was calculated to be as low as $6 \mathrm{nM}$ on the basis of $\mathrm{S} /$ $\mathrm{N}=3$, which indicates that TCF-MQ has excellent sensitivity to $\mathrm{NADH}$ and is more suitable for detecting NADH in living systems than DCI-MQ $($ LOD $=12 \mathrm{nM}) .{ }^{26}$

\section{Selective recognition of NAD(P)H by TCF-MQ}

To illustrate the good selectivity of TCF-MQ toward NAD $(\mathrm{P}) \mathrm{H}$, a series of biologically relevant species including inorganic salts, amino acids and reducing agents were evaluated. As shown in Fig. 3, compared with NADPH and NADH, inorganic salts $\left(\mathrm{K}^{+}, \mathrm{Na}^{+}, \mathrm{Ca}^{2+}, \mathrm{Mg}^{2+}, \mathrm{Zn}^{2+}, \mathrm{Fe}^{3+}\right.$, and $\mathrm{Fe}^{2+}$ ), amino acids (glycine, lysine, methionine, serine, cysteine, and homocysteine), reducing agents (glutathione, vitamin $\mathrm{C}$, dithiothreitol, $\mathrm{H}_{2} \mathrm{~S}_{2}$, and $\mathrm{SO}_{3}{ }^{2-}$ ), $\mathrm{NAD}^{+}, \mathrm{NADP}^{+}$and $\mathrm{FADH}_{2}$ did not cause obvious changes of the fluorescence intensity indicating that these do not interfere with the detection of $\mathrm{NAD}(\mathrm{P}) \mathrm{H}$. In addition, the reactivity of TCF-MQ toward ROS was also tested. The results showed that biologically relevant ROS, including 
$\mathrm{O}_{2}{ }^{\cdot-}, \mathrm{H}_{2} \mathrm{O}_{2}, \mathrm{NaClO}, t-\mathrm{BuOOH}$ and $\mathrm{NO}$, did not trigger any fluorescence changes in the probe solution (Fig. S5†). These results demonstrate that TCF-MQ can be employed for the specific recognition of $\mathrm{NAD}(\mathrm{P}) \mathrm{H}$ with high selectivity.

\section{Bioimaging of $\mathrm{NAD}(\mathrm{P}) \mathrm{H}$ in living cells}

After confirming the high sensitivity and selectivity of TCF-MQ for $\mathrm{NAD}(\mathrm{P}) \mathrm{H}$, we explored its application to imaging endogenous $\mathrm{NAD}(\mathrm{P}) \mathrm{H}$ in living cells. Before being applied in cell imaging, we first tested the cytotoxicity of this probe by an MTT assay. The result showed that the TCF-MQ probe exhibited negligible cytotoxicity when HepG2 cells were treated with 0-50 $\mu \mathrm{M}$ probe for $18 \mathrm{~h}$ (Fig. S6 $\dagger$ ). The resistance to photobleaching experiments showed that no obvious fluorescence decrease was observed when cells were exposed to laser radiation for $600 \mathrm{~s}$ (Fig. S7†), suggesting that the probe is stable and can be used as a viable probe in living cells.

Previous studies have shown that hypoxia can enhance $\mathrm{NAD}(\mathrm{P}) \mathrm{H}$ levels. ${ }^{36,37}$ Here, we investigated the imaging ability of TCF-MQ for NAD(P)H in HepG2 cells under hypoxia $\left(1 \% \mathrm{O}_{2}\right)$ and normoxia $\left(20 \% \mathrm{O}_{2}\right)$, respectively. HepG2 cells were cultured under hypoxic or normoxic conditions for $12 \mathrm{~h}$, and then incubated with $10 \mu \mathrm{M}$ TCF-MQ for 5-25 min. As shown in Fig. 4, the fluorescence of TCF-MQ became the brightest within $15 \mathrm{~min}$, and the fluorescence intensity under hypoxia was higher than that under normoxia, indicating that more $\mathrm{NAD}(\mathrm{P})$ $\mathrm{H}$ was generated in cells under hypoxia. This result indicates that the probe can be used to monitor the levels of $\mathrm{NAD}(\mathrm{P}) \mathrm{H}$ in living cells.

\section{Revealing reductive stress induced by natural antioxidants}

Next, we used the TCF-MQ probe to observe the NAD(P)H levels in the process of liver cancer cell death induced by natural antioxidants (resveratrol, curcumin and celastrol). HepG2 cells were exposed to different concentrations of resveratrol, curcumin and celastrol for different periods of time under hypoxic and normoxic conditions, respectively. After treatment, the cells were loaded with $10 \mu \mathrm{M}$ TCF-MQ for $20 \mathrm{~min}$, and then, the fluorescence was detected by confocal microscopy. Under hypoxic conditions, the HepG2 cells treated with $0-10 \mu \mathrm{g} \mathrm{mL}$ resveratrol for $6 \mathrm{~h}$ had a concentration-dependent increase in fluorescence. However, when the resveratrol concentration

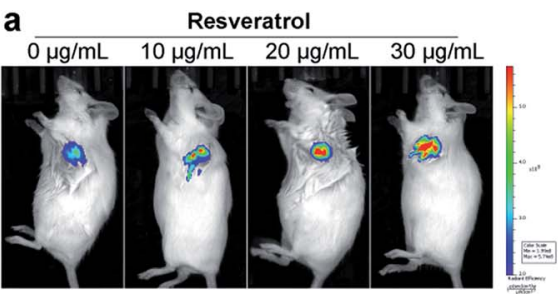

d

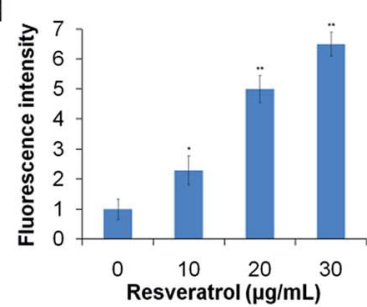

g

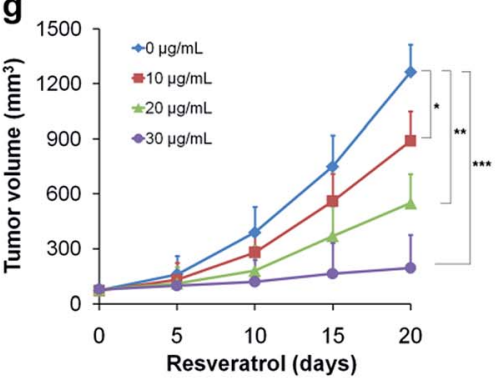

b

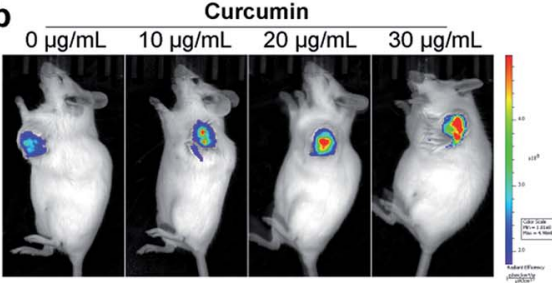

e

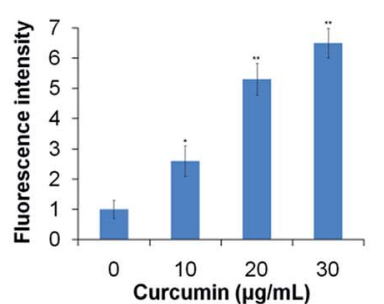

h

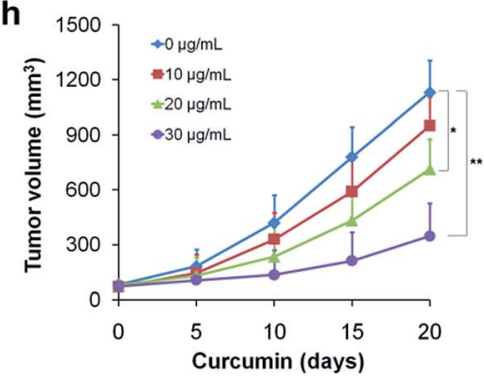

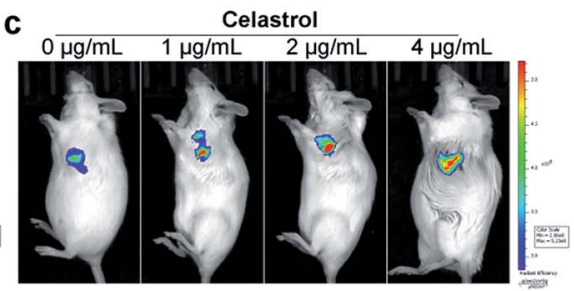

f
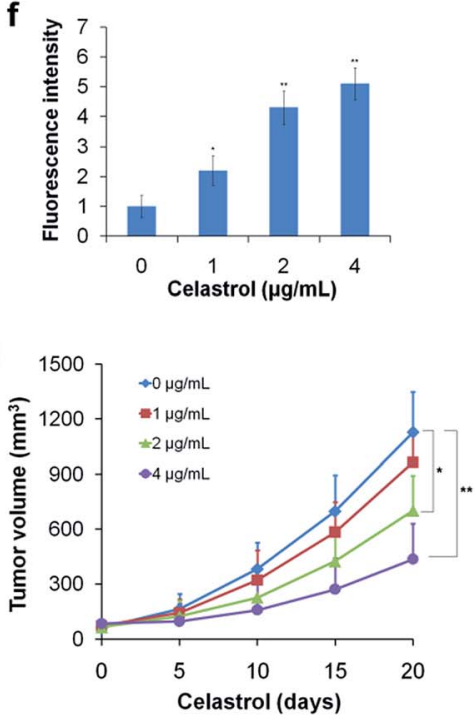

Fig. 6 Detection of NAD(P)H levels induced by natural antioxidants in vivo. (a) Tumor-bearing mice were treated with $0-30 \mu \mathrm{g} \mathrm{mL}{ }^{-1}$ resveratrol for 10 days, and then, $10 \mu \mathrm{M}$ TCF-MQ probe was subcutaneously injected into the tumor for 30 min before the fluorescence was analyzed using an in vivo imaging system. (b) Tumor-bearing mice were treated with $0-30 \mu \mathrm{g} \mathrm{mL}^{-1}$ curcumin for 10 days, then the TCF-MQ probe was added using the method described in (a). (c) Tumor-bearing mice were treated with $0-4 \mu \mathrm{g} \mathrm{mL}^{-1}$ celastrol for 10 days, and then the TCF-MQ probe was added using the method described in (a). (d) The quantitative fluorescence intensity for (a). (e) The quantitative fluorescence intensity for (b). (f) The quantitative fluorescence intensity for (c). (g) Tumor-bearing mice were treated with $0-30 \mu \mathrm{gL}^{-1}$ resveratrol for different number of days, and the tumor volumes were measured using digital calipers. (h) Tumor-bearing mice were treated with $0-30 \mu \mathrm{g} \mathrm{mL}{ }^{-1} \mathrm{curcumin}$ for different numbers of days, and the tumor volumes were measured using digital calipers. (i) Tumor-bearing mice were treated with $0-4 \mu \mathrm{g} \mathrm{mL}{ }^{-1} \mathrm{celastrol}$ for different numbers of days, and the tumor volumes were measured using digital calipers $(* p<0.05, * * p<0.01, * * * p<0.001, t$ test). 
reached $20 \mu \mathrm{g} \mathrm{mL}{ }^{-1}$, the fluorescence intensity decreased due to cell death (Fig. 5a, d and g). Additionally, after the HepG2 cells were treated with $10 \mu \mathrm{g} \mathrm{mL}{ }^{-1}$ resveratrol for $0-9 \mathrm{~h}$, the fluorescence intensity was also enhanced in a time-dependent manner (Fig. S8 $\dagger$ ). In contrast, under normoxic conditions, after the HepG2 cells were exposed to $0-20 \mu \mathrm{g} \mathrm{mL}{ }^{-1}$ resveratrol for $6 \mathrm{~h}$ or $10 \mu \mathrm{g} \mathrm{mL} \mathrm{m}^{-1}$ resveratrol for $0-9 \mathrm{~h}$, the cells exhibited much lower fluorescence compared with that under hypoxic conditions, and there was no enhancement of fluorescence in the process of cell death (Fig. 5a, d, g and S8 $\dagger$ ). Curcumin and celastrol showed similar results to resveratrol. When HepG2 cells were treated with curcumin or celastrol under hypoxic conditions, the fluorescence intensity of $\mathrm{NAD}(\mathrm{P}) \mathrm{H}$ was increased in a concentration- and time-dependent manner, but decreased with cell death (Fig. 5b-i). However, under normoxic conditions, only intracellular background fluorescence of TCFMQ was observed during cell death induced by curcumin and celastrol (Fig. S9 and $\mathrm{S} 10 \dagger$ ). These results indicate that reductive stress is involved in the process of HepG2 cell death induced by resveratrol, curcumin and celastrol, and cell death may be attributed to the reductive stress.

Because previous studies have shown that natural antioxidants (resveratrol, curcumin and celastrol) can stimulate the production of ROS in tumor cells cultured in vitro, ${ }^{4-6}$ we assessed whether oxidative stress was induced as HepG2 cells were treated with the above three natural antioxidants under hypoxic conditions. In this experiment, a previously described $\mathrm{H}_{2} \mathrm{O}_{2}$ probe was employed. ${ }^{38}$ HepG2 cells were exposed to resveratrol $\left(10 \mu \mathrm{g} \mathrm{mL}^{-1}\right)$, curcumin $\left(10 \mu \mathrm{g} \mathrm{mL}^{-1}\right)$ and celastrol (2 $\mu \mathrm{g} \mathrm{mL}^{-1}$ ) for 0-9 $\mathrm{h}$ under hypoxic conditions, respectively. Then, the cells were incubated with the $\mathrm{H}_{2} \mathrm{O}_{2}$ probe for $15 \mathrm{~min}$. As a result, there was no obvious increase in $\mathrm{H}_{2} \mathrm{O}_{2}$ levels in the three antioxidant treatment groups compared with the control group (Fig. S11-S13†). These results indicate that the three antioxidants do not cause oxidative stress under hypoxic conditions.

To further confirm the reductive stress induced by natural antioxidants in HepG2 cells under hypoxic conditions, we conducted a similar experiment in vivo. Tumor bearing mice were treated with different concentrations of resveratrol, curcumin and celastrol via subcutaneous injection at the tumor site for 10 days. After treatment, the mice received a subcutaneous administration of the TCF-MQ probe $(10 \mu \mathrm{M})$ into the tumor and were incubated for $30 \mathrm{~min}$. Then, fluorescence images were obtained using an in vivo imaging system. The fluorescence signal of the probe obviously increased in a dosedependent manner in the resveratrol treatment groups (Fig. 6a and d). Similar to the results for resveratrol, the fluorescence intensity of the probe was also enhanced in the curcumin and celastrol treatment groups (Fig. 6b, c, e and f), indicating that $\mathrm{NAD}(\mathrm{P}) \mathrm{H}$ levels were elevated during the treatment of liver cancer cells in mice with three natural antioxidants. These findings support the in vitro results obtained using the HepG2 cells under hypoxia showing that reductive stress was induced by treatment with natural antioxidants. The tumor volume measurement experiments showed that resveratrol could significantly inhibit tumor growth in a dose- and time- dependent manner (Fig. 6g). Curcumin and celastrol could also suppress the tumor growth in mice (Fig. 6h and i), indicating the reductive stress induced by three natural antioxidants can inhibit the growth of a liver cancer tumor.

\section{Conclusions}

In summary, we developed a novel small-molecule fluorescent probe, TCF-MQ, for monitoring $\mathrm{NAD}(\mathrm{P}) \mathrm{H}$ and revealing the reductive stress. TCF-MQ can rapidly respond to $\mathrm{NAD}(\mathrm{P}) \mathrm{H}$ with good selectivity and exhibited very high sensitivity to $\mathrm{NAD}(\mathrm{P}) \mathrm{H}$ with a low detection limit of $6 \mathrm{nM}$. The probe was successfully used to image endogenous $\mathrm{NAD}(\mathrm{P}) \mathrm{H}$ in living cells and to distinguish the different levels of $\mathrm{NAD}(\mathrm{P}) \mathrm{H}$ in HepG2 cells under normoxic conditions and hypoxic conditions. Moreover, with the help of TCF-MQ, we found that upon the treatment of HepG2 cells with pharmacological doses of three natural antioxidants (resveratrol, curcumin and celastrol) under hypoxic conditions, high levels of $\mathrm{NAD}(\mathrm{P}) \mathrm{H}$ were produced before cell death. The excess $\mathrm{NAD}(\mathrm{P}) \mathrm{H}$ resulted in reductive stress instead of oxidative stress. In contrast, under normoxic conditions, there was no obvious increase in $\mathrm{NAD}(\mathrm{P}) \mathrm{H}$ content in the process of cell death induced by resveratrol, curcumin and celastrol. Thus, we speculate that natural antioxidants might induce tumor cell death via reductive stress under the tumor hypoxic microenvironment, whereas under a normoxic environment, natural antioxidants induced cell death through oxidative stress based on previous reports. ${ }^{4-6}$ The mechanism of reductive stress inducing tumor cell death under hypoxic conditions is undergoing further research. Our findings reveal a new anti-cancer mechanism of resveratrol, curcumin and celastrol and provide a new research area for natural antioxidants.

\section{Experimental}

\section{Materials and methods}

3-Hydroxy-3-methyl-2-butanone, malononitrile, methyl trifluoromethanesulfonate and 3-quinolinecarboxaldehyde were purchased from Sun Chemical Technology (Shanghai, China). $\beta$-NADPH and $\beta$-NADH were obtained from Aladdin (Shanghai, China). Piperidine, sodium ethoxide, anhydrous ethanol, chloroform and acetonitrile were from Sinopharm Chemical Reagent (Shanghai, China). Resveratrol, curcumin and celastrol were from Dalian Meilun Biotechnology (Dalian, China). 3-(4,5Dimethyl-2-thiazolyl)-2,5-diphnyl-2 $H$-tetrazolium bromide (MTT) was from Sigma-Aldrich (St. Louis, MO, USA). ${ }^{1} \mathrm{H}$ NMR and ${ }^{13} \mathrm{C}$ NMR spectra were recorded on a nuclear magnetic resonance spectrometer (Advance $400 \mathrm{MHz}$, Bruker, Switzerland). High-resolution mass spectroscopy (HRMS) was performed on a high resolution quadrupole-time of flight mass spectrometer (Bruker, Germany). Fluorescence spectra were recorded on a fluorescence spectrometer (Edinburgh Instruments, U.K.). The fluorescence images were obtained with a confocal microscope (LSM 880, Zeiss, Germany). 


\section{Synthesis of the probe TCF-MQ}

Synthesis of compound 1. 3-Hydroxy-3-methyl-2-butanone (1 $\mathrm{mL}, 9.5 \mathrm{mmol})$ and malononitrile (1.3 g, $20 \mathrm{mmol})$ were added to $8 \mathrm{~mL}$ anhydrous ethanol sequentially to form a solution; then, sodium ethoxide $(0.1 \mathrm{~g}, 1.5 \mathrm{mmol})$ was added, and the solution was stirred at room temperature for $1.5 \mathrm{~h}$, and then refluxed at $60{ }^{\circ} \mathrm{C}$ for another $1 \mathrm{~h}$. After cooling to room temperature, the precipitate was filtered to give compound 1 (1.1 g, yield: $60 \%) .{ }^{1} \mathrm{H}$ NMR (chloroform- $d, 400 \mathrm{MHz}$ ): $\delta=2.37$ $(\mathrm{s}, 3 \mathrm{H})$ and $1.63(\mathrm{~s}, 6 \mathrm{H}) ;{ }^{13} \mathrm{C} \mathrm{NMR}$ (chloroform- $\left.d, 101 \mathrm{MHz}\right): \delta=$ 182.69, 175.25, 111.06, 110.44, 109.00, 104.80, 99.82, 58.44, 24.37, and 14.23. HRMS: (ESI, $m / z$ ) calcd for $\mathrm{C}_{11} \mathrm{H}_{9} \mathrm{~N}_{3} \mathrm{O}[\mathrm{M}-$ $\mathrm{H}]^{-}$: 198.0661 , found: 198.0694 .

Synthesis of compound 2 . Compound 1 (160 mg, $0.8 \mathrm{mmol})$ and 3-quinolinecarboxaldehyde $(151 \mathrm{mg}, 0.96 \mathrm{mmol})$ were dissolved in $15 \mathrm{~mL}$ anhydrous ethanol, two drops piperidine and acetic acid were added and the solution was refluxed for $2 \mathrm{~h}$. After cooling to room temperature, the precipitate was filtered to obtain compound 2 (190 mg, yield: 70\%). ${ }^{1} \mathrm{H}$ NMR (DMSO- $d_{6}$, $400 \mathrm{MHz}): \delta=9.41(\mathrm{~d}, J=2.2 \mathrm{~Hz}, 1 \mathrm{H}), 8.97(\mathrm{~d}, J=2.2 \mathrm{~Hz}, 1 \mathrm{H})$, $8.17-8.02(\mathrm{~m}, 3 \mathrm{H}), 7.88(\mathrm{t}, J=8.0 \mathrm{~Hz}, 1 \mathrm{H}), 7.71(\mathrm{t}, J=7.5 \mathrm{~Hz}, 1 \mathrm{H})$, $7.54(\mathrm{~d}, J=16.6 \mathrm{~Hz}, 1 \mathrm{H})$, and $1.86(\mathrm{~s}, 6 \mathrm{H}) ;{ }^{13} \mathrm{C}$ NMR (DMSO- $d_{6}$, $101 \mathrm{MHz}): \delta=177.55,174.96,150.90,148.84,144.48,137.41$, 132.15, 129.73, 129.37, 128.15, 128.08, 127.69, 117.49, 113.10, 112.26, 111.20, 100.91, 100.07, 55.37, and 25.56. HRMS: (ESI, $m$ / z) calcd for $\mathrm{C}_{21} \mathrm{H}_{14} \mathrm{~N}_{4} \mathrm{O}[\mathrm{M}+\mathrm{H}]^{+}$: 339.1240, found: 339.1208 .

Synthesis of TCF-MQ. A mixture of compound 2 (60 mg. 0.18 $\mathrm{mmol})$ and methyl trifluoromethanesulfonate $(0.1 \mathrm{~mL}, 0.92$ $\mathrm{mmol}$ ) in $5 \mathrm{~mL}$ trichloromethane was stirred at room temperature for $24 \mathrm{~h}$ under a nitrogen atmosphere. Ether was added after the solvent was removed in vacuo, and then the precipitate was filtered to give TCF-MQ (68 mg, yield: 75\%). ${ }^{1} \mathrm{H} \mathrm{NMR}$ (DMSO- $\left.d_{6}, 400 \mathrm{MHz}\right): \delta=10.05(\mathrm{~s}, 1 \mathrm{H}), 9.72(\mathrm{~s}, 1 \mathrm{H}), 8.56-8.54$ $(\mathrm{d}, J=8.0 \mathrm{~Hz}, 1 \mathrm{H}), 8.49-8.47(\mathrm{~d}, J=8.0 \mathrm{~Hz}, 1 \mathrm{H}), 8.36-8.34(\mathrm{q}, J=$ $8.0 \mathrm{~Hz}, 1 \mathrm{H}), 8.13-8.09$ (q, $J=8.0 \mathrm{~Hz}, 1 \mathrm{H}), 8.07-8.03(\mathrm{~d}, J=$ $16.0 \mathrm{~Hz}, 1 \mathrm{H}), 7.66-7.62(\mathrm{~d}, J=16.0 \mathrm{~Hz}, 1 \mathrm{H}), 4.67(\mathrm{~s}, 3 \mathrm{H})$, and 1.87 (s, 6H); ${ }^{13} \mathrm{C}$ NMR (DMSO- $d_{6}, 101 \mathrm{MHz}$ ): $\delta=177.27,173.43$, 150.93, 146.26, 140.07, 138.57, 137.12, 131.69, 131.21, 129.19, 128.82, 120.28, 119.91, 112.86, 112.05, 110.81, 103.48, 100.05, 100.00, 56.45, 46.18, and 25.50. HRMS: (ESI, $\mathrm{m} / \mathrm{z}$ ) calcd for $\mathrm{C}_{23} \mathrm{H}_{17} \mathrm{~F}_{3} \mathrm{~N}_{4} \mathrm{O}_{4} \mathrm{~S}[\mathrm{M}-\mathrm{TfO}]^{+}:$353.1396, found: 353.1385 .

\section{In vitro detection of $\mathrm{NAD}(\mathrm{P}) \mathrm{H}$}

The stock solution of TCF-MQ $\left(2 \times 10^{-3} \mathrm{M}\right)$ was prepared in DMSO. Stock solutions of $\mathrm{NAD}(\mathrm{P}) \mathrm{H}$ and various interfering reagents $\left(\mathrm{Na}^{+}, \mathrm{K}^{+}, \mathrm{Ca}^{2+}, \mathrm{Mg}^{2+}, \mathrm{Zn}^{2+}, \mathrm{Fe}^{2+}, \mathrm{Fe}^{3+}\right.$, glycine, lysine, serine, methionine, cysteine, homocysteine, glutathione, dithiothreitol, vitamin $\mathrm{C}, \mathrm{H}_{2} \mathrm{~S}_{2}, \mathrm{SO}_{3}{ }^{2-}, \mathrm{NAD}^{+}, \mathrm{NADP}^{+}, \mathrm{FADH}_{2}$, $\mathrm{H}_{2} \mathrm{O}_{2}$, NaClO, $t$-BuOOH, and $\mathrm{NO}$ ) were prepared in doubledistilled water, but superoxide anion free radicals $\left(\mathrm{O}_{2}{ }^{-\bullet}\right)$ were prepared from a solution of $\mathrm{KO}_{2}$ in DMSO. For spectral measurements, the stock solution of the TCF-MQ probe was diluted with PBS buffer to give a final concentration of $10 \mu \mathrm{M}$. $\mathrm{NAD}(\mathrm{P}) \mathrm{H}$ and various analytes were added to the solution of TCF-MQ $(10 \mu \mathrm{M})$ in PBS buffer $(10 \mathrm{mM}, \mathrm{pH}=7.4$, containing $0.5 \%$ DMSO). The fluorescence emission spectra were recorded in a range from $592-800 \mathrm{~nm}\left(\lambda_{\mathrm{ex}}=582 \mathrm{~nm}, \lambda_{\mathrm{em}}=610 \mathrm{~nm}\right.$, slit width: $5 \mathrm{~nm} / 5 \mathrm{~nm})$.

\section{Cell culture}

The cell culture was performed according to our previous paper. ${ }^{39}$ Briefly, HepG2 cells were cultured in DMEM (high glucose) supplemented with $10 \%$ FBS and $1 \%$ antibiotics $(100 \mathrm{U}$ $\mathrm{mL}^{-1}$ penicillin and $100 \mathrm{mg} \mathrm{mL}{ }^{-1}$ streptomycin) at $37{ }^{\circ} \mathrm{C}$ in a humidified atmosphere of $95 \%$ air $\left(20 \% \mathrm{O}_{2}\right)$ and $5 \% \mathrm{CO}_{2}$. For simulating the tumor hypoxic microenvironment, HepG2 cells were cultured in a mixture containing $1 \% \mathrm{O}_{2}, 94 \% \mathrm{~N}_{2}$ and $5 \%$ $\mathrm{CO}_{2}$ using a low oxygen incubator (Bugbox M, Ruskinn, England).

\section{Fluorescence imaging in living cells}

The fluorescence of $\mathrm{NAD}(\mathrm{P}) \mathrm{H}$ and $\mathrm{H}_{2} \mathrm{O}_{2}$ was detected by confocal microscopy. Briefly, HepG2 cells $\left(5 \times 10^{4}\right)$ were seeded on glass-bottom culture dishes $(15 \mathrm{~mm})$ for $24 \mathrm{~h}$. Then, the cells were exposed to different concentrations of three natural antioxidants for different periods of time under hypoxic and normoxic conditions, respectively. After treatment, the cells cultured under hypoxia and normoxia were simultaneously incubated with $10 \mu \mathrm{M}(1 \mathrm{~mL}) \mathrm{NAD}(\mathrm{P}) \mathrm{H}$ probe for $20 \mathrm{~min}$ or 10 $\mu \mathrm{M}(1 \mathrm{~mL}) \mathrm{H}_{2} \mathrm{O}_{2}$ probe for $15 \mathrm{~min}$ in FBS-free DMEM at $37^{\circ} \mathrm{C}$, and then, the cells were washed three times with PBS buffer and imaged immediately using a confocal microscope. The TCF-MQ probe was excited at $582 \mathrm{~nm}$ and the fluorescence emission range was set from $600-650 \mathrm{~nm}$. The $\mathrm{H}_{2} \mathrm{O}_{2}$ probe was excited at $532 \mathrm{~nm}$ and the fluorescence emission range was set from 600$700 \mathrm{~nm}$.

\section{Tumor model preparation and fluorescence imaging}

All animal experiments were performed according to the Principles of Laboratory Animal Care (People's Republic of China) and the Guidelines of the Animal Investigation Committee, and approved by the local Animal Care and Use Committee. Kunming mice were purchased from Qingdao Daren Fucheng Animal Co., Ltd. Hepatocellular carcinoma H22 cells $\left(1 \times 10^{7}\right)$ derived from mice were injected into the abdominal cavity of mice, and ascites was formed after 5-7 days. After three passages, ascites was used. We selected 8 week-old mice and injected H22 cells subcutaneously into the axillary lateral of the left forelimb at a density of $1 \times 10^{7}$ cells per mL with $100 \mu \mathrm{L}$ per mice. After 7 days, these mice were given different concentrations of natural antioxidants through subcutaneous injection at the tumor site for different periods of time. After treatment, the mice were subcutaneously injected with the TCF-MQ probe and incubated for $30 \mathrm{~min}$. Then, fluorescence images were obtained using an in vivo imaging system (IVIS) with $582 \mathrm{~nm}$ excitation and 600-650 $\mathrm{nm}$ to detect $\mathrm{NAD}(\mathrm{P}) \mathrm{H}$. In addition, the tumor volume was measured using digital calipers and calculated as volume $=0.5 \times\left(\right.$ length $\times$ width $\left.^{2}\right) .{ }^{40}$

\section{Conflicts of interest}

There are no conflicts to declare. 


\section{Acknowledgements}

This work was supported by the National Natural Science Foundation of China (21535004, 21575081, 21775091 and 91753111), the Key Research and Development Program of Shandong Province (2018YFJH0502), the Shandong Provincial Natural Science Foundation of China (ZR2014JL055) and the Key Research and Development Plan of Yantai City (2019XDHZ098).

\section{Notes and references}

1 D. Sinha, N. Sarkar, J. Biswas and A. Bishayee, Semin. Cancer Biol., 2016, 40-41, 209-232.

2 J. Y. Wang, X. Wang, X. J. Wang, B. Z. Zheng, Y. Wang, X. Wang and B. Liang, Eur. Rev. Med. Pharmacol. Sci., 2018, 22, 7492-7499.

3 S. Shrivastava, M. K. Jeengar, V. S. Reddy, G. B. Reddy and V. G. Naidu, Exp. Mol. Pathol., 2015, 98, 313-327.

4 D. J. Colin, E. Limagne, K. Ragot, G. Lizard, F. Ghiringhelli, É. Solary, B. Chauffert, N. Latruffe and D. Delmas, Cell Death Dis., 2014, 5, e1533.

5 F. Song, L. Zhang, H. X. Yu, R. R. Lu, J. D. Bao, C. Tan and Z. Sun, Food Chem., 2012, 132, 43-50.

6 J. H. Kim, J. O. Lee, S. K. Lee, N. Kim, G. Y. You, J. W. Moon, J. Sha, S. J. Kim, S. H. Park and H. S. Kim, Cell. Signalling, 2013, 25, 805-813.

7 L. J. Yan, J. Diabetes Res., 2014, 2014, 137919.

8 E. B. Rankin and A. J. Giaccia, Science, 2016, 352, 175-180.

9 N. C. Denko, Nat. Rev. Cancer, 2008, 8, 705-713.

10 X. X. Xiong, X. Y. Qiu, D. X. Hu and X. Q. Chen, Mol. Pharmacol., 2017, 92, 246-255.

11 X. X. Fan, H. D. Pan, Y. Li, R. J. Guo, E. L. Leung and L. Liu, Pharmacol. Ther., 2018, 191, 148-161.

12 M. Inoue, R. Nakashima, M. Enomoto, Y. Koike, X. Zhao, K. Yip, S. H. Huang, J. N. Waldron, M. Ikura, F. F. Liu and S. V. Bratman, Nat. Commun., 2018, 9, 5116.

13 B. Petrova, K. Liu, C. Tian, M. Kitaoka, E. Freinkman, J. Yang and T. L. Orr-Weaver, Proc. Natl. Acad. Sci. U. S. A., 2018, 115, E7978-E7986.

14 N. S. Rajasekaran, P. Connell, E. S. Christians, L. J. Yan, R. P. Taylor, A. Orosz, X. Q. Zhang, T. J. Stevenson, R. M. Peshock, J. A. Leopold, W. H. Barry, J. Loscalzo, S. J. Odelberg and I. J. Benjamin, Cell, 2007, 130, 427-439.

15 H. Zhang, P. Limphong, J. Pieper, Q. Liu, C. K. Rodesch, E. Christians and I. J. Benjamin, FASEB J., 2012, 26, 14421451.

16 D. E. Handy and J. Loscalzo, Free Radical Biol. Med., 2017, 109, 114-124.

17 S. Dimmeler and A. M. Zeiher, Cell, 2007, 130, 401-402.

18 A. C. Brewer, S. B. Mustafi, T. V. Murray, N. S. Rajasekaran and I. J. Benjamin, Antioxid. Redox Signaling, 2013, 18, 1114-1127.
19 H. Komatsu, Y. Shindo, K. Oka, J. P. Hill and K. Ariga, Angew. Chem., Int. Ed. Engl., 2014, 53, 3993-3995.

20 V. A. Aleshin, A. V. Artiukhov, H. Oppermann, A. V. Kazantsev, N. V. Lukashev and V. I. Bunik, Cells, 2015, 4, 427-451.

21 L. Yuan, W. Y. Lin, K. B. Zheng, L. W. He and W. M. Huang, Chem. Soc. Rev., 2013, 42, 622-661.

22 J. Yin, Y. Kwon, D. Kim, D. Lee, G. Kim, Y. Hu, J. H. Ryu and J. J. Yoon, J. Am. Chem. Soc., 2014, 136, 5351-5358.

23 X. Ao, S. A. Bright, N. C. Taylor and R. B. P Elmes, Org. Biomol. Chem., 2017, 15, 6104-6108.

24 A. Tirla and P. Rivera-Fuentes, Angew. Chem., Int. Ed. Engl., 2016, 55, 14709-14712.

25 A. Tirla and P. Rivera-Fuentes, Chimia, 2018, 72, 241-244.

26 C. A. Roeschlaub, N. L. Maidwell, M. R. Rezai and P. G. Sammes, Chem. Commun., 1999, 1637-1638.

27 C. Tu, R. Nagao and A. Y. Louie, Angew. Chem., Int. Ed., 2009, 48, 6547-6551.

28 S. O. Jung, J. Y. Ahn and S. Kim, Tetrahedron Lett., 2010, 51, 3775-3778.

29 H. Komatsu, Y. Shindo, K. Oka, I. P. Hill and K. Ariga, Angew. Chem., Int. Ed., 2014, 53, 3993-3995.

30 M. A. Fomin, R. I. Dmitrev, J. Jenkins, D. B. Papkovsky, D. Heindl and B. Konig, ACS Sens., 2016, 1, 702-709.

31 L. Wang, J. Zhang, B. Kim, J. Peng, S. N. Berry, Y. Ni, D. Su, J. Lee, L. Yuan and Y. T. Chang, J. Am. Chem. Soc., 2016, 138, 10394-10397.

32 Y. Zhao, K. Wei, F. Kong, X. Gao, K. Xu and B. Tang, Anal. Chem., 2018, 91, 1368-1374.

33 C. Zhang, L. R. Dalton, M.-C. Oh, H. Zhang and W. H. Steier, Chem. Mater., 2001, 13, 3043-3050.

34 W. Bentoumi, J. C. Mulatier, P. A. Bouit, O. Maury, A. Barsella, J. P. Vola, E. Chastaing, L. Divay, F. Soyer, P. Le Barny, Y. Bretonnière and C. Andraud, Chemistry, 2014, 20, 8909-8913.

35 A. C. Sedgwick, H. H. Han, J. E. Gardiner, S. D. Bull, X. P. He and T. D. James, Chem. Commun., 2017, 53, 12822-12825.

36 L. B. Jiang, L. Cao, Y. Q. Ma, Q. Chen, Y. Liang, F. L. Yuan, X. L. Li, J. Dong and N. Chen, Osteoarthr. Cartil., 2018, 26, 138-148.

37 O. Polesskaya, A. Sun, G. Salahura, J. N. Silva, S. Dewhurst and K. Kasischke, J. Visualized Exp., 2012, 3466.

38 X. Liu, B. Hu, R. Cheng, F. Kong, X. Pan, K. Xu and B. Tang, Chem. Commun., 2016, 52, 6693-6696.

39 X. H. Pan, X. X. Song, C. Wang, T. T. Cheng, D. R. Luan, K. H. Xu and B. Tang, Theranostics, 2019, 9, 1794-1808.

40 W. S. Henry, T. Laszewski, T. Tsang, F. Beca, A. H. Beck, S. S. McAllister and A. Toker, Cancer Res., 2017, 77, 790-801. 